\title{
An Analysis Of Market Reaction To Chief Executive Turnover Announcement In Indonesia: A Trading Volume Approach
}

Doddy Setiawan, Universitas Sebelas Maret, Indonesia

Santoso Tri Hananto, Universitas Sebelas Maret, Indonesia

Phua Lian Kee, Universiti Sains Malaysia, Malaysia

\begin{abstract}
This research aims at examining market reaction to Chief Executive Officer (CEO) turnover announcements using trading volume approach. The sample of this research consists of 67 CEO turnover announcements without confounding effects and 117 CEO turnover announcements with confounding effects during the period 1992-2003 from Indonesian Stock Exchange. The authors use a t-test to examine the hypotheses. The results for market reaction to CEO turnover announcements using sample firms without confounding effect show that the trading volume before and after the CEO turnover announcements is not significantly different. In contrast, the trading volume before and after the CEO turnover for sample with confounding effect is significantly different. The results show that Indonesian investors consider other confounding events along with the CEO turnover announcements to make investment decisions. Analysis is also conducted to examine the influence of the succession process and the origin of the new CEO on the market reaction toward CEO turnover announcements. We do not find significant difference between the trading volumes before and after the CEO turnover announcement without confounding effect under both organizational contexts. On the other hand, we find significant difference between the trading volumes for non-routine CEO turnover announcements with confounding effects. This suggests that non-routine CEO turnover contains useful information to investors. In addition, significant difference in the trading volume between before and after nonroutine CEO turnover with outside successors implies that Indonesian investors expect the incoming CEO from the outside to improve the performance of the company after the turnover process.
\end{abstract}

Keywords: Chief Executive Officer; Turnover; Trading Volume; Succession Process

\section{INTRODUCTION}

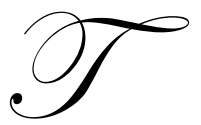

his research aims at examining market reaction to Chief Executive Officer (CEO) turnover. Based on the efficient market hypothesis (EMH) theory (Fama, 1970), CEO turnover announcement is an event that contains useful information to the investors (Foster, 1986). It is argued that CEO turnover announcements convey good news if the event is in line with shareholders' interests. On the other hand, it conveys bad news if the firm performance is poorer than the expectation. Empirical evidence on the market reaction to CEO turnover provides mixed results. There is evidence of positive reaction (Dahya \& McConnell, 2005; Denis \& Denis, 1995; Huson, Malatesta, \& Parrino, 2004), negative reaction (Dedman \& Lin, 2002; Suchard, Singh, \& Barr, 2001), and insignificant reaction (Reinganum, 1985; Warner, Watts, \& Wruck, 1988). As CEO turnover contains mixed signals - both good and bad news (Warner, et al., 1988) - the inconsistent results could be due to mixed signals from the CEO turnover. In other words, market reaction is the sum of positive reaction to good news and negative reaction to bad news. 
Most previous research that applied the event study approach to examine how markets reacted to CEO turnover announcements did not include CEO turnover announcements with confounding effect. However, Graffin, Carpenter, and Boivie (2011) argued and found that the CEO turnover announcements, as well as other corporate actions/announcements made during the succession, are inter-related. They suggested that both CEO turnover announcements with and without confounding effect should be taken into consideration in an attempt to analyze how markets react to the announcements. Dedman and Lin (2002), using samples with and without confounding effect, found that the UK markets reacted negatively to CEO turnover announcements. The result is robust and they concluded that the UK investors perceived such announcements as bad news. It is noted that the majority of previous research on market reactions to CEO turnover was conducted in Western developed countries. In Asia, research on market reactions to CEO turnover conducted by Kang and Shivdasani (1995) in Japan and Setiawan (2008) in Indonesia reported positive abnormal returns. This means that the markets perceive CEO succession as a change to be followed by improvement of a firm's performance, or good news; therefore, the markets reacted positively.

The present study attempts to enhance the understanding of how investors react to CEO turnover announcements in an emerging country; namely, Indonesia, by analyzing CEO turnover announcements with and without confounding effects. Research found that some companies intentionally release other corporate actions simultaneously along with the CEO turnover announcement (Graffin, et al., 2011). As an emerging market, Indonesia is characterized as a market with concentrated ownership structures, which gives rise to a different aspect of agency problems as compared to developed countries. Due to highly concentrated ownership, it is argued that the minority shareholders are more prone to be exploited by the major shareholders. Hence, it is important to investigate how markets react to announcements of CEO turnover with and without confounding effect. In addition, Indonesia implements a two-tier board system, which means that there are two boards - the board of directors and the board of commissioners. The board of directors is responsible for managing the operations of the firm, while the role of the board of commissioners is to supervise the board of directors. The CEO is the chairperson of the board of directors and CEO duality is not allowed in Indonesia. As pointed out by Friedman and Singh (1989), organizational context and organizational content affect market reactions toward CEO turnover announcements. We believe that the different institutional context of Indonesia will provide further insight to understand the relations between market reaction to CEO turnover announcements and hence, enrich the literature.

This study will first examine the market reaction to CEO turnover to announcements with confounding effect and without confounding effect. Then we will consider the origin of the successor (insider or outsider) and the turnover process (routine or non-routine) to analyze the reaction of investors to CEO turnover announcements. In order to study the effects of the competing signals from CEO turnover announcements, Cools and van Praag (2007) suggest to analyze the trading volume around the CEO turnover announcements. Therefore, this research uses a trading volume approach to examine market reaction. The trading volume approach analyzes the volume of transactions around the CEO turnover announcement.

\section{LITERATURE REVIEW AND HYPOTHESIS DEVELOPMENT}

Research on CEO turnover has attracted great attention as the CEO is the key person who leads a firm to compete in the market and plays an important role in determining the strategy and performance of the firm. If the leadership of the CEO fails to further improve the firm's performance and instead lets the firm suffer from prolonged poor performance, he/she will be scrutinized by the internal and external control mechanisms of the firm and is most likely to be dismissed.

Foster (1986) argues that CEO turnover contains useful information. This implies that market will react to the release of such news. Empirically, Weisbach (1988), Denis and Denis (1995) and Huson, Malatesta and Parrino (2004) found positive market reactions to CEO turnover announcements in the U.S. On the other hand, Reinganum (1985) and Warner, et al. (1988) did not find significant market reactions. In the UK, researchers also reported mixed results. Dahyaa and McConnel (2005) showed there is evidence that markets reacted favorably to CEO turnover announcements and found positive abnormal returns around the CEO turnover announcements. On the other hand, the results of the study conducted by Singh and Barr (2001), using Australian data, reported negative reactions and they concluded that investors in Australia perceived CEO turnover as bad news. 
Dedman and Lin (2002) investigated the relations between CEO turnover processes and the market reaction in the UK. Their sample consisted of 24 fired turnovers, 28 voluntary sign offs, 22 normal turnovers, and 10 CEOs who moved to other firms. Their study showed that markets reacted negatively to fired turnovers, voluntary sign offs, and those who moved to other firms. This suggested that the UK investors perceive CEO turnovers as bad news. As an attempt to conceal the bad news arising from the CEO turnover announcements, companies intentionally announced other good news along with the CEO turnover announcements. The result is robust as the investors still reacted negatively to the announcement of CEO turnovers, even with the presence of confounding events.

In the emerging markets, Setiawan (2008) investigated how Indonesian investors reacted to the CEO turnover announcements using abnormal return. The result of his study showed that markets reacted positively to the announcements, which means that Indonesian investors perceive CEO turnover announcements as good news. In an earlier study, Setiawan (2007) did not find significant security return variance around the CEO turnover announcements in Indonesia.

Lako (2002) argued that the main weakness of most empirical studies regarding market reactions to earnings announcements is the failure to take into account the confounding effects that have occurred around the earnings announcements. As a result, research on market reaction to earnings announcements produced inconsistent results. Lako (2002) also argued that the existence of confounding events may have a significant effect on the stock price and trading volume. He found that markets reacted differently to negative earnings announcements between samples with confounding effects and samples without confounding effects for the 1998 period. This result implies that the impact of confounding effects on market reaction to CEO turnover or other useful information should also be taken into consideration

Graffin, et al. (2011) investigated companies' strategies around the succession of CEOs in the US. They found that information about other corporate actions is simultaneously released along with CEO turnover announcements among the firms. They referred such phenomenon as strategic noise around CEO turnover. As CEO turnover announcements were associated with other confounding events, they suggested that future research on CEO turnover using an event study approach should include both confounding and non confounding effects.

Cools and van Praag (2007) investigated market reactions to top executive turnover announcements in the Netherlands. Their sample consisted of 343 executive departures during 1991-1999. They used stock price movement and trading volume approaches to measure market reaction. Their findings showed that there is no significant abnormal return around the announcements of top executive turnovers. Their result supported Warner, et al. (1988). They further claimed that the insignificant result was due to mixed reactions among investors. To overcome the problem, they analyzed trading volume during the succession announcement. They then found significant trading activity around the announcements and concluded that the Netherlands' investors reacted to the top executive turnover announcements. Based on the discussion presented above, the first hypothesis of this study is:

$\mathbf{H}_{01}$ : There is no difference between the trading volumes before and after CEO turnover announcements.

\section{Market Reaction to Routine and Non-routine Turnover}

CEO succession could be a routine or non-routine process. Denis and Denis (1995) investigated the effects of the routine and non-routine processes on CEO turnover. They examined 69 CEO turnovers. The results showed that investors reacted positively to both non-routine and routine CEO turnovers with $2.5 \%$ and $0.61 \%$ change in the abnormal return, respectively. They also found that investors' reactions to non-routine change are larger under the normal CEO transitions.

Neumann and Voetmann (2005) investigated market reactions to CEO turnover announcements in Denmark. Their sample consisted of 39 non-routine changes and 42 voluntarily changes for the period of 19941998. The results of their research showed that markets reacted positively to non-routine changes, but negatively to routine changes. This suggests that Denmark's investors reacted more favorably to non-routine changes as compared to routine changes. Dherment-Ferere and Reneboog (2002), using data of France's companies, supported the results 
of Neumann and Voetmann (2005). Dedman and Lin (2002) investigated the effects of CEO turnovers on market reactions in the UK. They showed that markets react negatively to the processes of being fired, voluntarily signed off, and moving to other firms. Based on the above findings and observations, the hypothesis to test for routine and non-routine CEO turnover is:

$\mathbf{H}_{02}$ : There is no difference between the trading volumes for routine (non-routine) CEO turnovers before and after CEO turnover announcements.

\section{Market Reaction to Inside and Outside CEO Turnover}

Another important factor that affects investors' reactions toward CEO turnover announcements is the origin of the successor; i.e., inside or outside the firm. Dherment-Ferere and Reneboog (2002) argued that the advantages of incoming CEOs from inside the firm are: 1) he/she has a better vision and understanding about the firm's internal condition, product, market, competition with the rivals, and relationship with the clients and 2) he/she has a better social network, thus he/she can get specific information more readily. On the other hand, they argued that incoming CEOs from outside the firm are able to maintain the corporate image, especially when the firms are under financial distress or suffer from poor performance. Another advantage from the appointment of an outside CEO is that he/she will bring a new vision to the firm and a new passion to reach a better position in the market.

Boards of directors tend to choose successor candidates from outside when the firm has a poor performance (Farrel and Whidbee, 2003). It is argued that if the board chooses an internal candidate when the firm suffered from poor performance, it would further deteriorate the firm's image as the internal candidate is perceived to be jointly responsible for the poor performance of the firm.

Worrel, Davidson III and Glascock (1993) found that outside CEOs increase stockholders' wealth, but inside CEOs did not show a similar outcome. On the other hand, the research conducted by Dahya and McConnell (2005) and Kang and Shivdasani (1996) showed that investors reacted positively to the successors of both origins; i.e., inside and outside. However, markets reacted more favorably to outside CEOs as compared to inside CEOs. Charitou, Patis, and Vlittis (2010) also found positive market reactions to the announcement of outside incoming CEOs in the US. This result shows the market perceives that outside incoming CEOs bring positive influences to the firms' performances. On the other hand, Dherment-Ferere and Reneboog (2002) did not find significant market reactions to both origins (i.e., inside and outside incoming CEOs) of the successor. This means the market did not react to the action of hiring an outside CEO when a firm suffered from poor performance. Similarly, when the firm achieved good performance and hired an inside CEO to maintain the existing conditions, investors did not react to such action. In conclusion, Dherment-Ferere and Reneboog (2002) found that the market perceived CEO turnover as not having useful information content.

Based on literature review that shows inconsistent results about market reactions to CEO turnover announcements regarding the origin of the successor from inside and outside the firm (Dahya \& McConnell, 2005; Dherment-Ferere \& Renneboog, 2002; Kang \& Shivdasani, 1996; Worrel, et al., 1993), the following hypothesis is formulated:

$\mathbf{H}_{03}$ : There is no difference between the trading volumes for inside (outside) incoming CEOs before and after CEO turnover announcements.

\section{Market Reaction to Routine (Non-routine)/Inside (Outside) CEO Turnover Announcement}

The present study also attempts to analyze market reactions to CEO turnover announcements by examining a combination of the organizational factors - routine turnover with inside incoming CEO, routine turnover with outside incoming CEO, non-routine turnover with inside incoming CEO, and non-routine turnover with outside incoming CEO.

Kang and Shivdasani (1996) investigated the combining effect of the organizational factors on the market reactions to CEO turnovers in Japan. They found interesting results - that markets reacted to CEO turnover 
announcements when the process was non-routine and involved the promotion of an outside candidate. The results suggested that Japanese investors perceive that non-routine processes are associated with a new leadership style that differs from the former CEO. Therefore a more suitable candidate should come from outside the organization. Kang and Shivdasani (1996) also found a positive abnormal return around non-routine outside CEO turnovers.

When inside candidates were appointed as the CEO under a non-routine turnover, the market did not react. This is because as an inside candidate, the new CEO is perceived to be jointly responsible for the poor performance of the firm. In addition, it is also believed that he/she will follow a similar approach or management style of the former CEO in leading the firm.

On the other hand, investors appreciate the inside candidate if the turnover process is routine. The findings showed that markets reacted positively to routine-inside CEO changes. It is argued that inside candidates would be able to continue with the same management strategy to defend the firm's market position. Clayton, Hartzell and Rosenberg (2005) argued that an inside CEO has a better understanding of a firm's business conditions, thus he/she can lead the firm with a similar strategy. They also found that the market did not react to outside candidates if the process is routine.

Setiawan (2007) found significant return variance for routine-inside and non-routine-outside turnover among Indonesian firms. The results showed that Indonesian investors reacted to non-routine turnovers when the successor was appointed from outside the firm. On the other hand, they reacted to routine turnovers when the successor was an internal candidate. Setiawan (2008) found positive abnormal return for routine-inside turnover. Meanwhile, Indonesian investors reacted negatively to routine-outside CEO turnover. This result showed that Indonesian investors prefer an inside incoming CEO when the succession process is normal. Based on literature review, the following hypothesis will be tested:

$\mathbf{H}_{04}$ : There is no difference between the trading volumes before and after routine (non-routine) inside (outside) CEO turnover announcements.

\section{RESEARCH METHODOLOGY}

This research applies an event study approach. The objective of the event study is to test the trading volume before and after a specific event; namely, the CEO turnover announcements. The CEO turnover announcements are classified into two groups - announcements with and without confounding effects. One with confounding effects refers to announcements of other corporate actions/activities, such as dividend declarations, bonus shares, stock split, merger and acquisition, and right issues during a specified window period. The window period is 21 days and 41 days around the CEO turnover announcement. The hypotheses are tested by using a t-test. The sample of this research consists of Indonesian-listed firms with observations collected from January 1, 1992 to December 31, 2003.

The Chief Executive Officer refers to the top position of the firm, also known in Bahasa Indonesia (Indonesian language) as Direktur Utama and Presiden Direktur. The CEO turnover process can be identified as routine and non-routine. Routine change is a well planned and well structured process, while the non-routine process is unstructure. This research looks for related articles about CEO turnovers in the national newspapers, including Neraca, Kompas, and Business News, in order to determine the CEO change process (routine or non-routine). If related articles are not available, the authors follow Kang and Shivdasani (1996) to identify the succession process. According to Kang and Shivdasani (1996), if the departing CEOs is appointed as the chairperson or a member of the Board of Commissioners, the succession process is considered non-routine. However, if the departing CEO does not become a member or the chairperson of the Board of Commissioners, the succession process is considered nonroutine. The origin of CEO is classified as having inside and outside changes. An inside CEO change is defined as a person who works for a minimum of three years in the firm as an employee or if the person has a family relation with the outgoing CEO. 


\section{ANALYSIS}

\section{Descriptive Statistics}

The total number of CEO turnover announcements is 117 . There are 50 announcements with confounding effects and 67 without confounding effects. The confounding events consist of 43 dividend announcements, three bonus share announcements, two stock split announcements, one right issue announcement, and one M\&A announcement. The descriptive statistics show that most of the confounding effects are the announcements of dividend declaration.

Overall, the number of non-routine CEO turnover is greater than routine turnover. There are 62 non-routine versus 55 routine processes for CEO turnover announcements with confounding effects and 42 compared to 25 for CEO turnovers without confounding effects. The authors also found that most of the successors are from inside the firm rather than from the outside, there are 62 inside CEO compared to 55 outside CEO turnovers for CEO turnover announcements with confounding effects and 35 inside CEO turnovers compared to 32 outside CEO turnovers for CEO turnover announcements without confounding effects.

Interestingly, when the authors combine the turnover factors; i.e., the process and origin of the successor, it is noted that most of the events "match". Specifically, if the CEO turnover is routine, the successors are likely to come from inside the firms. A routine CEO turnover means the succession is normal; therefore, the firms prefer to choose the successor from inside the firm. As the inside CEO is well versed in the firm's business strategy, he/she does not need to take much effort to adapt to the environment. However, if the CEO turnover process is non-routine, the successor is likely to be appointed from outside the firm. This indicates that if the CEO turnover process is nonroutine, the firm needs a new management approach and thus, an outside CEO is preferred over an inside CEO.

\section{Market Reaction to CEO Turnover Announcements with Confounding Effect}

This section discusses market reactions to CEO turnover announcements with confounding effects.

Table 1: Market Reaction to CEO Turnover Announcements with Confounding Effects

\begin{tabular}{lcc}
\hline \multicolumn{1}{c}{ Sample } & $\begin{array}{c}\text { T-test for trading volume 10 days } \\
\text { before compare to trading volume } \\
\text { days after the announcements }\end{array}$ & $\begin{array}{c}\text { T-test for trading volume 20 days } \\
\text { before compare to trading volume } 20 \\
\text { days after the announcements }\end{array}$ \\
\hline All firms & 1,601 & $1,775^{*}$ \\
Routine CEO turnover & 0,955 & 1,067 \\
Non-routine CEO turnover & 1,396 & $1,798^{*}$ \\
Inside CEO Turnover & 1,184 & 1,331 \\
Outside CEO Turnover & 1,073 & 1,252 \\
Routine inside CEO Turnover & 1,236 & 1,298 \\
Routine outside CEO Turnover & $-0,704$ & $-0,964$ \\
Non-routine inside CEO turnover & $-0,174$ & 0,367 \\
Non-routine outside CEO turnover & 1,49 & $1,779^{*}$ \\
\hline
\end{tabular}

Significant at $10 \%$

From Table 1, the t-test for trading volume during the period of 21 days around the CEO turnover announcements does not find a significant difference between the trading volume 10 days before and 10 days after the announcements for the sample firms. These results show that investors do not use information about CEO turnover announcements to make investment decisions.

When the authors analyze the turnover process - routine and non-routine - there is no difference between the trading volume before and after the announcements. The authors also find the same results in the analysis of the origin of successor - inside and outside the firm. There is no difference between the trading volume before and after the announcements. The subsequent test is to analyze the combination of the turnover process and the origin of the successor. Again, the authors do not find a significant difference between the trading volume before and after CEO 
turnover announcements for routine inside turnover, routine outside, non-routine inside turnover, and non-routine outside. The test results derived from all the hypotheses on the trading volume 10 days before and 10 days after the CEO turnover announcements show that there is no difference in the trading volume within the time period under investigation.

The test results on the difference between the trading volume 20 days before and 20 days after the CEO turnover announcements (41 days around the announcements) show that the market reacts to the events. The t-value of the difference between trading volume for all samples is 1.775 (significant at $10 \%$ ). This result rejects the null hypothesis and accepts the alternative hypothesis. This suggests that there is difference between the trading volume before and after CEO turnover announcements. This result also confirms that CEO turnover announcements have information content which prompted investors to react. The result supports Setiawan (2008) who found positive reactions around the CEO turnover announcements as indicated by a positive abnormal return.

The results of market reaction to CEO turnover announcements by considering the turnover process show that there is a difference between the trading volume before and after the non-routine turnover process; however, there is no difference between the trading volume before and after the routine CEO turnover process. This suggests that the announcement of non-routine CEO turnover contains useful information to the investors. Table 1 shows that markets do not react to the origin of CEO successors. There is no difference between the trading volume before and after inside and outside CEO turnover. These results show that Indonesian investors do not consider the origin of the successor in their investment decision. However, when the authors consider both contextual factors, the findings indicate that the outside successor has information content when the turnover process is non-routine.

This result is interesting as non-routine turnovers usually take place when there are problems in the firm. As discussed in the literature, when a firm suffers from poor performance, the board's decision to elect an internal candidate as the new CEO would make the firm's image even more negative as the newly appointed internal candidate is considered responsible for the firm's poor performance. On the other hand, an outside CEO is perceived to bring a new vision to the firm and a passion to reach a better position in the market. Therefore, a successor who comes from outside is preferable. Farrel and Whidbee (2003) also argued that the board tends to choose outside candidates when the firms have a poor performance.

\section{Market Reaction to CEO Turnover Announcements without Confounding Effects}

This section discusses market reactions to the CEO turnover announcements using sample without confounding effects.

Table 2: Market Reaction to CEO Turnover Announcements without Confounding Effects

\begin{tabular}{lcc}
\hline \multicolumn{1}{c}{ Samples } & $\begin{array}{c}\text { T-test for trading volume 10 days } \\
\text { before compare to trading volume } \\
\mathbf{1 0} \text { days after the announcements }\end{array}$ & $\begin{array}{c}\text { T-test for trading volume 20 days } \\
\text { before compare to trading volume 20 } \\
\text { days after the announcements }\end{array}$ \\
\hline All samples & 0,699 & 0,842 \\
Routine CEO turnover & $-0,386$ & $-0,397$ \\
Non-routine CEO turnover & 1,038 & 1,276 \\
Inside CEO Turnover & 0,268 & 0,405 \\
Outside CEO Turnover & 0,642 & 0,733 \\
Routine inside CEO Turnover & 0,316 & 0,273 \\
Routine outside CEO Turnover & $-0,951$ & $-1,463$ \\
Non-routine inside CEO turnover & $-0,031$ & 0,337 \\
Non-routine outside CEO turnover & 1,071 & 1,216 \\
\hline
\end{tabular}

From Table 2, the results show that there is no significant difference between the trading volume 10 days before and 10 days after the CEO turnover for all samples. This result shows that the market does not react to CEO turnover announcements. The following analysis examines how markets react to CEO turnover announcements by considering the turnover process - routine and non-routine. The findings indicate that there is no difference between the trading volume 10 days before and 10 days after the events. This result suggests that the market does not use this information to make investment decisions. 
The market also did not use the information about the origin of successor when the CEO turnover announcements were released. There is no significant difference between the trading volumes within the 21 days around the announcements. When the authors combine the contextual factors, there are no significant results. The results show that the market did not react to CEO turnover announcements without confounding effects; therefore, there is no difference between trading volume 10 days before and 10 days after CEO turnover announcements.

From Table 2, the test results on comparison between the trading volumes 20 days before and 20 days after the announcements are in line with the results using a 21 -day window period (i.e., trading volume 10 days before and 10 days after the announcements). There is no significant difference in the trading volume for all the tests. The finding that markets do not react to the CEO turnover announcement implies that investors are not making investment decisions upon the release of such information. The market also does not react differently to CEO turnover announcements when the turnover process and the origin of successor are being compared. The results also show that there is no significant difference between the trading volumes 20 days before and 20 after the announcements when the authors examine the following contextual factors: 1) routine inside turnover, 2) routine outside turnover, 3) non-routine inside turnover, and 4) non-routine outside turnover.

\section{CONCLUSION}

The results of analyzing of the market reactions to CEO turnover announcements without confounding effects using a trading volume approach show that there is no market reaction toward the announcements. The result shows that markets do not rely on the release of such information for investment decisions. The result supports Reinganum (1985) and Warner, et al. (1988) who found that there is no abnormal return around the turnover announcements date. However, this result is contradictory to Charitou, et al. (2010), Cools and van Praag (2007), Dahya and McConnell (2005), Dedman and Lin (2002), Denis and Denis (1995), Huson, et al. (2003), Kang and Shivdasani (1996), Suchard, et al. (2001), and Weisbach (1988), which show that there are significant abnormal returns around the announcement dates. This result does not support Setiawan (2008) which shows that there is significant abnormal return around the announcement date. This means Indonesian investors react to the CEO turnover announcements in the form of change in the share price, but the transaction volumes are not significantly different.

However, when the authors examine the sample with confounding effects, a significant difference is noted between the trading volumes between 20 days before and 20 days after the announcements. The results show that CEO turnover with confounding effects contains useful information content; therefore, the market reacts. The authors also find that markets react to non-routine turnover CEO announcements. When the authors combine both contextual factors - turnover process and origin of the successor - there is significant market reaction to the nonroutine outside CEO turnover. The market perceives that non-routine turnover needs an outside successor to enhance the firms' performance. The results also indicate that the market takes longer to react to CEO turnover announcements. This result supports previous research by Setiawan $(2007,2008)$ which found that markets reacted significantly when the process of turnover and the origin of incoming CEO were taken into consideration.

The results suggest that Indonesian investors consider all confounding events; for instance, micro-events such as dividends, earnings, and other information released around the CEO turnover announcements, to make investment decisions. These results support Lako (2002) and Graffin, et al. (2011) who argued that investors consider other corporate actions to make investment decisions.

\section{ACKNOWLEDGEMENT}

We thank Niken Perwitasari, Rulli Legha Hariwibawa, Wahyanti, and Wati Rochayani for their research assistance and Payamta, Salamah Wahyuni, and Sunardi for their valuable suggestions. 


\section{AUTHOR INFORMATION}

Doddy Setiawan is a lecturer in Accounting at Faculty of Economics, Universitas Sebelas Maret, Indonesia. His research interest is in the areas of corporate governance, earnings management and financial accounting. E-mail: doddy.setiawan@gmail.com.

Santoso Tri Hananto is a lecturer in Accounting at Faculty of Economics, Universitas Sebelas Maret, Indonesia and has served as Head of Accounting Department. His research interest is in the areas of corporate governance, public sector accounting and accounting information system. E-mail: sthananto@yahoo.com

Phua Lian Kee is a senior lecturer in Accounting at School of Management, Universiti Sains Malaysia. She has more than 15 years of experience in teaching Financial Accounting. She was appointed as the chief examiner for an Accounting paper of a professional examination body from 2006 to 2009. She also serves as a member of the editorial board of AAM Journal of Accounting and Finance and has presented papers at national and international conferences. Her main research interest is in the areas of voluntary disclosure, financial reporting and corporate governance. E-mail: phualk@usm.my

\section{REFERENCES}

1. Charitou, M., Patis, A., \& Vlittis, A. (2010). The market reaction to the appointment of outside CEO: an empirical investigation. Journal of Economics and International Finance, 2(11), 272-277.

2. Clayton, M. C., Hartzell, J. C., \& Rosenberg, J. (2005). The impact of CEO turnover on equity volatility. Journal of Business, 78(5), 1779-1808.

3. Cools, K., \& van Praag, C. M. (2007). The value relevance of top executive departures: Evidence from the Netherlands. Journal of Corporate Finance, 13(5), 721-742.

4. Dahya, J., \& McConnell, J. J. (2005). Outside directors and corporate board decisions. Journal of Corporate Finance, 11(1-2), 37-60.

5. Dedman, E., \& Lin, S. W. J. (2002). Shareholder wealth effects of CEO departures: evidence from the UK. Journal of Corporate Finance, 8(1), 81-104.

6. Denis, D. J., \& Denis, D. K. (1995). Performance changes following top management dismissals. The Journal of Finance, 50(4), 1029-1057.

7. Dherment-Ferere, I., \& Renneboog, L. (2002). Share price reactions to CEO resignations and large shareholders monitoring in large French listed companies. In J. A. McCahery, P. Moerland, T. Raaijmakers \& L. Renneboog (Eds.), Corporate Governance Regime: Convergence and Diversity (pp. 297-324). New York: Oxford University Press.

8. Fama, E. F. (1970). Efficient Capital Market: A Review of Theory and Empirical Work. The Journal of Finance, 25, 383-417.

9. Farrell, K. A., \& Whidbee, D. A. (2003). Impact of firm performance expectations on CEO turnover and replacement decisions. Journal of Accounting and Economics, 36(1-3), 165-196.

10. Foster, G. (1986). Financial Statement Analysis (Vol. 2nd. edition): Prentice-Hall International.

11. Friedman, S. D., \& Singh, H. (1989). CEO Succession and Stockholder Reaction: The Influence of Organizational Context and Event Content. Academy of Management Journal 32(4), 718-744.

12. Graffin, S. D., Carpenter, M. A., \& Boivie, S. (2011). What's all that (strategic) noise? anticipatory impression management in CEO succession. Strategic Management Journal forthcoming.

13. Huson, M. R., Malatesta, P. H., \& Parrino, R. (2004). Managerial succession and firm performance. Journal of Financial Economics, 74(2), 237-275.

14. Kang, J.-K., \& Shivdasani, A. (1995). Firm performance, corporate governance, and top executive turnover in Japan. Journal of Financial Economics, 38(1), 29-58.

15. Kang, J.-K., \& Shivdasani, A. (1996). Does the Japanese Governance System Enhance Shareholder Wealth? Evidence from the Stock-Price Effects of Top Management Turnover. The Review of Financial Studies, 9(4), 1061-1095.

16. Neumann, R., \& Voetmann, T. (2005). Top executive turnovers: separating decision and control rights. Managerial and Decision Economics, 26(1), 25-37. 
17. Reinganum, M. R. (1985). The Effect of Executive Succession on Stockholder Wealth. Administrative Science Quarterly, 30(1), 46-60.

18. Setiawan, D. (2007). Variabilitas return saham di sekitar pengumuman pergantian Chief Executive Officer. Jurnal Ekonomi dan Bisnis Indonesia, 22(2), 180 - 196.

19. Setiawan, D. (2008). An analysis of market reaction to CEO turnover announcements: the case in Indonesia International Business \& Economics Research Journal, 7(2), 119 -127.

20. Suchard, J.-A., Singh, M., \& Barr, R. (2001). The market effects of CEO turnover in Australian firms. Pacific-Basin Finance Journal, 9(1), 1-27.

21. Warner, J. B., Watts, R. L., \& Wruck, K. H. (1988). Stock prices and top management changes. Journal of Financial Economics, 20(3), 461-492.

22. Weisbach, M. S. (1988). Outside directors and CEO turnover. Journal of Financial Economics, 20, 431460.

23. Worrel, D. L., III, W. N. D., \& Glascock, J. L. (1993). Stockholders Reaction to Departures and Appointments of Key Executive Attributable to Firing. Academy of Management Journal 36(2), 387-401. 